\title{
Pensions and Retirement on the Agenda
}

\author{
Helen Desmond $\star$
}

In the last year or so it appears that not a day goes by without something on pensions being mentioned in the press or on the media. When it emerged, in December 1991, that anomalies had been discovered in pension funds of companies the late Robert Maxwell had controlled, anomalies which were subsequently revealed as $£ 420$ million in missing assets, pensions were already firmly on the agenda. That event (described as a spectacular fraud) ensured that it would remain so, probably until legislation is introduced to set an entirely new single statutory framework for the operation of pension funds.

The problem which has to be faced in so doing is to find the middle ground between assuring the individual that his financial contributions will be well looked after and produce a reasonable pension at the end of the day, being protected from the various catastrophes which can occur along the way, and encouraging employers to continue to believe that the increased costs and inconvenience of complying with protections are in fact worthwhile and that it is in their interests to continue to provide a company based scheme for employees' pension provision.

The alternative scenario is to change fundamentally the way in which financial provision is made post retirement, which could involve the employer, or series of employers, in financial contributions but not in administration or pension payment.

\section{Existing agenda items}

The decision of the European Court in May 1990 in Barber v. Guardian Royal Exchange Assurance Group, ${ }^{1}$ raised the profile of pensions considerably. The resulting high profile campaign by the pensions industry as to their preferred interpretation of the Barber judgment, together with a host of cases, ${ }^{2}$ has meant

${ }^{\star}$ Lecturer in Law, University of Buckingham.

1. (Case 262/88) [1990] I.R.L.R. 240.

2. Roscoe v. Hick Hargreaves [1991] (EAT/205/91 Lexis); W. F. Lee v. Shell U.K. (unreported); Keary, Roberts \& Searle v. Gullick Dobson Ltd. [1991] (unreported); Neath v. Hugh Steeper Ltd. [1991] P.L.R. 91; and see Helen Desmond, "A tangled web: Barber and beyond - a research report", (1992) I.R.J. Vol. 23, No. 3 . 
that literature landing on the desks of employment and pensions lawyers and personnel specialists will today invariably carry pensions news of various kinds.

The failure of Denmark to ratify the Treaty on monetary and political union agreed by the European Community heads in Maastricht in December 1991 again raised the vexed question of retrospectivity following Barber. ${ }^{3}$ The Maastricht Treaty contains a Protocol which restricts the need to backdate pensions equality not only to pensions paid after the date of the Barber judgment, 17th May 1990, but also to benefits accrued after that date. ${ }^{4}$ The protocol will, of course, not become effective unless or until the Treaty is ratified by all member states. ${ }^{5}$

The spotlight therefore falls once more on Coloroll Pension Trustees Ltd. Russell, Mangham and Others. The trustees wish to wind up the schemes following the appointment of receivers in June 1990 . However, in order to do so they need to know what provision has to be made in terms of accrued benefits.

In short, do they need to provide funds for equalisation of benefits from May 1990, from the date each member joined the scheme, or even from the date of ratification of the Treaty of Rome? ${ }^{6}$

Coloroll was referred by the High Court to the European Court in July 1991 and was due to be heard later this year, along with a case from Holland and one from Germany, all of which are seeking to clarify different aspects of the Barber decision. ${ }^{7}$

\section{See Ian Cowie, "A £40bn morning after feeling", Daily Telegraph, 6th June 1992.}

4. "For the purposes of Article 119 of the Treaty establishing the European Community benefits under Occupational Social Security Schemes shall not be considered as remuneration if and insofar as they are attributable to period of employment prior to 17th May 1990,...".

5. Anna Kelly, "Following Protocol", (1992) Pensions World, February. If the European Court holds Barber to be retrospective 16 electricity companies, who are members of the Electricity Supply Pension Scheme, intend taking action under Article 215 against the Council of Europe for damages because the companies relied on the Commission and Council's interpretation of Article 119 and "due to misrepresentation and violation of Community law by the Commission and the Council" they were led to believe that this Article did not yet apply to private occupational pension schemes: IDS Pensions Service Bulletin, Issue No. 54: April 1992.

6. As was held in $W . F$. Jones v. Foxboro International (unreported) but noted "Pensions \& Equal Treatment", Labour Research Department, September 1991.

7. G.C. Ten Oever v. Stichting Bedrijfspensioensfonds voor het Glazenzuassers en Schoonmaakbedrijf [1991] P.L.R. 105; Michael Moroni v. Firm Collo GmbH [1991] P.L.R. 53. It is understood that the three cases are now to be heard in January 1993. The European Court commenced hearing the three cases week commencing 25th January 1993. See also Sara McConnell, "Weighing up cost of equality in a battle of sex and age", The Times, 21st January 1993.

On 28th April 1993 Advocate General Van Gerven delivered his opinion in the four joined cases:- Ten Oever v Stichting Bedrijfspensioenfonds voor het Glazenwassers-en Schoonaakbedrijf (Case C-109/91), Moroni v Firma Collo GmbH (Case C-110/91), Neath v Hugh Steeper Ltd. (Case C-152/91) and Coloroll Pension Trustees Ltd. v Russell, Managham (Case C-200/91).

In addition to the following brief summary the Advocate General also considered the question of where liability for breaches of Article 119 lay, whether Article 199 applies to non-contributory schemes and the effect on schemes consisting of only one sex:- 
In addition, the consultation period for the Government's discussion document putting forward the options for amending discriminatory state pension ages, expired in June $1992 .{ }^{8}$ The discussion document was published in December 1991 following increasing pressure to equalise state pension ages, and a decision is awaited as to how the Government proposes to equalise the age of eligibility for state retirement pension.

The Government originally appeared to favour a flexible approach, such as that put forward by the pensions industry. ${ }^{9}$ However, recent reports suggest that the Government now believes that the administrative complexities of flexibility giving, say, a decade during which one could choose when to retire, would be too great and that they now favour a common state pension age. The House of Lords' European Communities Committee, when backing the recommendation of the Commons Social Services Select Committee, recommended a common age of 63 . However, in its response to the Department of Social Security on equalising State pension ages, the Social Security Advisory Committee has recommended progressively equalising at age 65 and this now appears to be the preferred option,

1. The Advocate General interpreted Barber to mean that the principle of equal treatment should only be applied to benefits payable in respect of periods of service after 17th May 1990. Periods of service prior to that date would not be affected by the direct effect of Article 119. By this interpretation he is selecting the least expensive option of those put forward. The Advocate General went on to point out that "The interpretation of the temporal limitation of the effects of the Barber judgment which I propose here largely coincides with that adopted in the protocol on A119 annexed to the Treaty on European Union. I would, moreover, point out that if the Court should come to a different conclusion, its decision would be entirely superseded as soon as the Treaty on European Union comes into force". par (a 23)

2. In addition, the Barber decision, as interpreted above, applies not only to final salary schemes but "to all occupational pensions schemes" (para 26)

3. Actuarial factors cannot vary as to sex, "at least insofar as this leads to men and women paying different contributions or receiving different benefits".

4. Article 119 applies equally to spouses.

5. Article 119 affects trustees of pension schemes as well as employers and trustees are obliged to do everything in their powers in order to ensure that benefits comply with the principle of equality. 6. Where a scheme does not comply with Article 119 the pension benefits of the disadvantaged sex must be brought up to the level of those of the advantaged sex. "However, Community law does not prevent new scheme rules, adapted to the principle of equal treatment, which relate to periods of service in the future, from reducing pension benefits, so long as those benefits are set at a level which is the same for men and women".

See "Consulting Update", The Alexander Consulting Group, May 1993. See also, Diana Wright, "All Pensions are now equal but some are more equal ...", The Sunday Times, 2nd May 1993

8. "OPTIONS for Equality in State Pension Age", Cmnd. 1723, December 1991.

9. Pensions Management Institute; see "Equalising State Pension Ages - A Discussion Document", National Association of Pension Funds, March 1991. See also, response to the DSS consultation paper by Legal \& General, "Equalising the State Pension Age", June 1992. 
equalising at 60 or 63 being too expensive. ${ }^{10}$ This option will undoubtedly attract opposition from some quarters ${ }^{11}$ and will be seen as turning Barber on its head. Instead of giving to men acces to the benefits enjoyed by women, as was intended, the outcome could well be just denying women the benefit at all.

\section{Social Security Committee}

It is against this background, "and the consequences that were predicted to arise for the pensions industry if pension funds were forced retrospectively to give equal treatment to all members", 12 that the Social Security Committee, under the Chairmanship of Frank Field, decided to investigate various aspects of pension funds. This developed into "a debate on the whole question of the ownership and control of pension fund assets and in turn took on a greater significance and public profile when the calamitous events surrounding the pension funds of the private and public companies controlled by Mr. Robert Maxwell became known."'13

It is perhaps worth noting the importance that pension funds play in the economy as a whole. "Almost half the adult population of the United Kingdom are members or beneficiaries of non-state pension schemes. Over 11 million employees are members of occupational pension schemes, and five million are covered by personal pension plans and about six million people receive occupational pensions. The growth of coverage of occupational pension schemes is reflected in the growing importance of these pensions in the distribution of personal wealth. Although overall, people's homes are the largest single form of personal wealth, the value of occupational pension rights was estimated in 1989 to

10. Ralph Atkins and Norma Cohen, Financial Times, 21st April 1992; I.D.S. Pensions Service Bulletin Issue No. 58: September 1992. Estimates of the cost of equalising state pension ages have varied widely. The Treasury estimates the cost of equalisation at 60 at $£ 3.5$ billion a year, equalisation at 63 producing a saving of $£ 500$ million a year and a common pension age of 65 at a saving of $£ 3$ billion a year. The TUC estimates equalisation at 60 would cost only $f 0.7$ billion and that equalising at 65 would actually cost $£ 1.4$ billion.

It was widely expected that a White Paper would be published in April this year and that a bill would be included in the Queen's Speech in November. The Treasury has pushed for a common age of 65, and a saving of $£ 3$ billion a year. However, it is reported that Government fears at the change is a potential vote-loser among women and wants a longer campaign to prepare the ground before it is put to Parliament', Andrew Grice, The Sunday Times, 18th April 1993.

It was subsequently reported that on 20th April Peter Lilley, Social Security Secretary, told the Social Security Committee that there would be no early white paper on a single retirement age, The Times, 21st April 1993.

11. Institute of Personnel Management, "Personnel Management", September 1992, who point out that equality at 65 would bring the U.K. into line with the rest of Europe, i.e. Italy and Germany, France is currently reconsidering its earlier decision to equalise pension ages at 60 . The trend in the U.K. is towards earlier retirement, with the vast majority of women retiring at 60 or before and over 50\% of men retiring before 65: "A Question of Fairness", Equal Opportunities Commission.

12. Social Security Committee Second Report, "The Operation of Pension Funds", March 1992, para. 1; "Pension rights equality could send companies to the wall": Daily Telegraph, 29th June 1991. The CBI estimated the cost of retrospection at $£ 50$ billion; Labour Research, October 1991, quoting Bryn Davies of Union Pension Services, put the figure closer to $£ 10$ billion.

13. Supra, para. 1. 
be equal to about $70 \%$ of the wealth stored in housing. In 1988, the latest year for which figures are available, occupational pensions formed $23 \%$ of the gross income of all pensioner units (single people over state pension age and couples where the man is over 65 ), and $37 \%$ of the gross income for those $57 \%$ of pensioner units with any income from an occupational pension." 14

"The market value of shares owned by pension funds rose over eight-fold during the last decade" and have as a result increased their ownership of stock market securities from $6.4 \%$ of registered company shares in 1963 to $31.4 \%$ by 1990 and are "by far and away the most important single holder of these securities." 15

Yet, as pointed out by the Social Security Committee, until the large-scale loss of pension funds from pension schemes run by Maxwell "there was little overt public appreciation either of the value of pension rights or of the significant holdings in the stock market held on behalf of pension contributors" which the report calls a 'blackout". The single good deed Maxwell has done for pensioners generally was to ensure that the ownership and control of pension schemes was "now high on the political agenda". 16

The Committee made a number of recommendations, principle amongst which was that they were in no doubt about the urgent need to reform the law as it applied to pension funds and that this should be done by the introduction of a pensions bill. They recommended the immediate establishment of a Departmental Committee or Royal Commission to undertake the task under a strict timetable.

\section{Government responses}

Early in June 1991 newspaper reports began to appear that Peter Lilley, Secretary of State for Social Security, was expected to announce a wide-ranging review of pensions law and regulation. This followed increased activity, described as a revolt, by a group of more than 100 all party M.P.'s, an impending report by I.M.R.O. to the Securities and Investment Board, which it was believed would be critical of its own supervision of pension funds, and an opposition debate on the Maxwell pensions scandal.

Peter Lilley said that Government accepted the Social Security Committee's main recommendation that an enquiry should be established to collect evidence on what the detailed structure of a new Pensions Act should be, and on Monday 8th June, the day more than 2000 Maxwell pensioners lobbied Parliament, he duly announced the setting up of a Pension Law Review Committee under the Chairmanship of Royston Goode, Professor of English Law at Oxford University, to carry out a wide ranging review covering the rights and interests of scheme members, trustees, pensioners and employers and to report within a year;

14. "Consultation Document on the Law and Regulation of Occupational Pension Schemes", Pensions Law Review Committee, September 1992, para 3.1.

15. Social Security Committee, supra n. 12, para. 19.

16. Ibid., para. 20. 
reporting any recommendations for urgent action earlier if possible. ${ }^{17}$

In the light of the Maxwell revelations the Government had already started a rearguard action when, in February 1992, Tony Newton, Secretary of State, announced the implementation, from 9th March, of previously unimplemented provisions contained in Social Security Act 1990; this restricted trustees investing more than $5 \%$ of the fund in either the sponsoring company, or any other company connected with it, and where existing investments exceeded the 5\% limit arrangements were to be made for a progressive reduction to the $5 \%$ level. This was seen as a welcome, if somewhat belated, protection which some would have preferred had gone further - to a complete ban on self-investment. ${ }^{18}$

Following the announcement of the establishment of the Goode Committee the Secretary of State, under pressure from opposition and backbench M.P.'s, as well as all sides in the pension debate, responded in a haphazard way in various areas as if putting out a series of bush fires.

First, in the area of compensation: there is no compensation scheme for employees whose pension fund fails to provide them with their anticipated pension and whose lifelong savings, as well as those paid on their behalf by their employer as part of their salary package, is squandered or fraudulently misappropriated, or just fails to provide the promised pension as a result of poor investment performance or poor management. This contrasts sadly with the arrangements that exist for holiday makers.

Bonding has long formed a part of the package holiday market and is a selling point when booking one's annual holiday because of the protection it offers should the company go out of business either after parting with one's money or while actually away on holiday. As a result of a European Directive, ${ }^{19}$ which came into

17. The Committee's terms of reference are: "To review the framework of law and regulation within which occupational pension schemes operate, taking into account the rights and interests of scheme members, pensioners and employers; to consider in particular the status and ownership of occupational pension funds and the accountability and roles of trustees, fund managers, auditors, and pensions scheme advisers; and to make recommendations."

Membership of the committee is as follows: Professor Roy Goode, Chairman; Tony Atkinson, Professor of Economics at L.S.E.; David Berridge, Chief Executive, Scottish Equitable Life Ass.; Harvie Brown, Actuary and Principal, William Mercer Fraser Ltd.; Bryan Hines, formerly General Manager, Insurance \& Investments, I.C.I. p.l.c.; Stuart James, Partner, Rowe and Maw; Terence Libby, Chairman and Chief Executive, Morrisflex Ltd.; Alastair Ross Goobey, Chief Investment Strategist, James Capel; Patricia Triggs, Partner KPMG Peat Marwick McLintock; Sue Ward, Freelance journalist and researcher on pensions issues.

18. i.e.., the National Association of Pension Funds.

19. Directive $90 / 314$, brought into effect by Package Travel: Package Holidays and Package Tours Regulations 1992. 
effect on 1st January 1993, existing bonding arrangements were extended to all inclusive travel, not by the introduction of one bonding scheme, but by the extension of the existing proliferation of schemes. ${ }^{20}$ The Government has in turn given an undertaking that in the event of the Air Travel Trust, whose funds have declined from some $£ 26$ million to $£ 5$ million as a result of a number of failures, being unable to meet claims the Government would meet them directly.

It is, therefore, somewhat bizarre that the nearest the government of the day has come to awarding compensation to the victims of the Maxwell fraud was to announce, as late as 29 th June 1992, that the Government would provide temporary emergency funding equal to $£ 2.5 \mathrm{~m}$ for the benefit of pensioners of the M.C.C. empire - but excluding pensioners of other companies Maxwell acquired and whose schemes he promptly raided, e.g. British International Helicopters. ${ }^{21}$ The Government also announced that it was to establish a trust fund, under the Chairmanship of Sir John Cuckney, which would call for and administer voluntary contributions from financial institutions and other private sector donors, which would be used for the benefit of pensioners affected by the Maxwell fraud.

The contrast between the treatment of these two types of situations almost belies belief. What sort of society is it that values its holidays to a greater degree than the repayment of a lifetime's savings for, not great comfort, but some additional income in retirement over and above that which reliance on a state pension and social security benefits would bring? ${ }^{22}$

Secondly, on the question of a deficiency when a scheme is wound-up: the Social Security Act 1990 contains provisions under which a deficiency on the winding-up of a pension scheme, or when the employer goes into liquidation,

20. A.T.O.L. currently covers inclusive air tours, A.B.T.A. inclusive travel arranged through approved travel agents, F.S.A. shipping inclusive travel and a number of other such schemes.

21. On 27th October 1992, Ann Widdecombe, Social Security Minister, announced in the House that the government still had $£ 1.5 \mathrm{~m}$ in the fund and that $£ 1 \mathrm{~m}$ had been distributed to 5,500 pensioners, deferred pensioners and those retiring because of ill health, whose payments were at risk.

22. The National Association of Pension Funds has supported the implementation of a compulsory risk-related compensation scheme to be triggered when an employer goes into liquidation and there is a shortfall in the fund. National Association of Pension Funds Ltd. Discussion Paper, "A Proposal For A Compensation Scheme For Occupational Pensions", 2nd November 1992. See now Liz Dolan, "NAPF abandons protection proposals", The Times, 18th December 1992. The chairman, Brian MacMahon, reported that new proposals, reflecting the views of the majority of N.A.P.F. membership after a "record mailbag" would mean that the proposed scheme would now only apply in cases of fraud, theft or criminal negligence. If the original proposals had gone through, the country's second-biggest pension fund, the Electricity Supply Pension Scheme, threatened to resign from the Association. The proposals form part of the N.A.P.F submission to the Goode Committee. 
becomes a debt on the employer. ${ }^{23}$ Amid the high excitement created by the possible retrospectivity of the Barber decision Tony Newton, the Secretary of State for Social Security at the time, announced that implementation of this provision would await clarification of the Barber decision. However, somewhat in haste, regulations were laid before Parliament on 30th June 1992, which came into force on lst July bringing into effect these provisions. ${ }^{24}$ This debt applies in respect of any occupational pension scheme, whether tax approved or not, and whether funded or not, unless it is a money purchase scheme.

The view is that the regulations have been introduced in great haste and apply to schemes currently in the process of winding up in an attempt to ensure that the trustees of any Maxwell scheme which is wound up can have recourse to any assets held by the company concerned. This will require a view to be taken on whether the sex equality requirements in Article 119 of the Treaty of Rome have been adequately provided for or whether additional funding will be required to cover retrospection. No consultation with the profession took place before the regulations were implemented and no guidance has been issued. Despite this lack of planning and execution in the introduction of the regulations, they are pretty meaningless and offer virtually no protection to scheme members because the host company, being insolvent, is likely to have somewhat limited resources and since the debt is unsecured the pensioners and beneficiaries are likely to be some way down the list of creditors.

Thirdly, in connection with disclosure of information: the Social Security Committee recommended that members should have a right to receive more information on their pension funds' portfolio, including in what form the assets are held and where deposited. Indeed, the Committee saw the right to information of various kinds as a means of empowering members and enabling them to question trustees on their stewardship of the fund. The Government's response was to announce, on 29th June 1992, that members of occupational pension schemes would indeed be entitled to much more information from trustees and administrators about their funds.

With effect from 28th September 1992, further disclosure requirements on trustees were duly brought into effect. ${ }^{25}$ These in general call for tighter timelimits in providing pension scheme information and the provision of basic scheme information to members. Audited accounts must be produced within 12 months of the end of the scheme year and copies must be made available to members on request within one month.

23. Schedule 4, para. 2 which introduced a new para. (58B) into the Social Security Pensions Act 1975. 24. The Occupational Pension Schemes (Deficiency on Winding Up etc.) Regulations 1992 (SI 1992/1555): see "Funding To Be Employer's Debt on Winding Up", Occupational Pensions (1992), October.

25. The Occupational \& Personal Pension Schemes (Miscellaneous Amendments) Regulations 1992 (SI 1992/1531). 
However, the provisions of the Social Security Act 1990, which require final salary schemes to pay indexed pension increases up to a maximum of $5 \%$ in respect of future service, and past service where the scheme is in surplus, have yet to be implemented. Tony Newton, as Secretary of State for Social Security, announced in June 1991 that these were not to be implemented "in view of the substantial financial uncertainties faced by occupational pension schemes as a result of the Barber judgment." 26

Likewise, an announcement has yet to be made regarding the implementation of Social Security Act 1989, section 23 and Schedule 5. These provisions implement the requirements of Directive $86 / 378$ prohibiting discrimination in domestic pension schemes, the final date for implementation of which was 1st January 1993. As drafted the provisions have been largely overtaken by the Barber decision but no announcement as to proposals for the introduction of the remaining provisions of the Directive have been made.

\section{The Pension Law Review Committee}

Some five months after being set up, the Pension Law Review Committee published a consultative document in which they describe the status quo and pose a number of questions to which pensions advisers and other interested parties were invited to respond by 15 th December. A final report is due by Autumn 1993.27

Professor Goode has said that the committee would be considering two main issues: how far UK pension law provides fair treatment to all the parties involved, and the security of funds. The Committee is also proposing a survey into how much employees know about their own pension funds. ${ }^{28}$

\section{Trust as a basis for occupational pension schemes}

The Social Security Committee examined the arguments advanced by earlier committees for the abolition of "medieval trust law" as the underlying basis upon which occupational pension schemes are established and run. ${ }^{29}$ That company pensions schemes do have trusts as their basis is a matter of convenience rather than design, and became entrenched as a framework when the Inland Revenue made it the basis upon which tax relief was granted, relief which in 1991/92 amounted to $£ 9,100$ million. ${ }^{30}$ Although, as was pointed out to the Committee,

26. Mr. Newton said in the House on 26th June 1991 that "there is no question of our having dropped limited price indexation..."

27. Consultation Document on the Law and Regulation of Occupational Pension Schemes, Pension Law Review Committee, September 1992. As a result of an overwhelming response to the consultation exercise, Peter Lilley agreed to a three-month extension of time, and final recommendations are therefore to be made by 30 th September.

28. The Times, 18th September 1992.

29. Report of the Committee to review the functioning of financial institutions, Cmnd. 7937, 1980; Review of Investor Protection: A discussion document, HMSO, 1982; Review of Investor Protection: Cmnd. 9125, 1984.

30. Social Security Committee Report, Section 4, Table 3. 
there now also exists "about 2,500 pages of statute law...",31 the Select Committee concluded that the Wilson Committee ${ }^{32}$ was right in 1980 in recommending that a new legal basis should be sought, and that it should be analogous to the law which regulates companies. ${ }^{33}$

The Wilson Committee observed that "the framework within which occupational pension schemes in the United Kingdom operate has grown piecemeal and now needs to be systematised and strengthened. It is unsatisfactory in our view that so much of it should depend on a body of trust law developed for quite other purposes." 34 The committee notes that this point was explored further by the Gower Committee ${ }^{35}$ and again by the Occupational Pensions Board who observed in their 1982 Report that: "The concepts developed in trust law become rather strained when applied to a modern pension scheme. Under trust law the employer is considered to be the 'settlor' who endows that trust from which the members or 'beneficiaries' draw their pensions, overlooking the fact that the members as well as the employer often contribute to the scheme and the employer's contributions can scarcely be considered as an act of unilateral benevolence." ${ }^{36}$ However, in their 1989 Report the Occupational Pensions Board were somewhat more reserved regarding the need to change the legal basis upon which pension funds are based..$^{37}$

The Social Security Committee based their criticism of trust law on the power that companies can exercise over occupational schemes they have set up. It is the employer who drafts the trust deed and as the Pension Law Review Committee points out: "present law allows the employer a wide measure of freedom in determining the content of the trust deed and scheme rules and the balance of power between the employer and the trustees. In particular, it is for the employer to determine the categories of employee eligible for scheme membership (so long as there is no illegal discrimination), the classes of beneficiary under the scheme, the contribution rates, the conditions of pension entitlement, the benefits to be provided and the circumstances in which benefits are forfeited or made subject to the exercise of discretion by the trustees. In addition, the employer may, by the terms of the trust deed, reserve the right:

- to appoint and remove trustees, actuaries and other advisers;

- to appoint as sole trustee a trust company which is a wholly owned subsidiary of the employer;

31. Ibid., para. 55.

32. Report, supra n. 29.

33. Supra n. 30 , paras. 74 and 75.

34. Ibid., para. 25.

35. Review of Investor Protection: A discussion document, HMSO 1982; Review of Investor Protection, Cmnd. 9125, 1984.

36. Occupational Pensions Board, Cmnd. 8649, 1982, para. 31: quoted Social Security Committee. 37. "Protecting Pensions - Safeguarding Benefits In a Changing Environment", Report by the Occupational Pensions Board, Cmnd. 573, February 1989. 
- to limit the powers and duties of trustees and their liability for breach of trust not amounting to wilful default;

- to determine investment strategy;

- to reduce or suspend contributions;

- to approve benefit increases proposed by the trustees;

- to reclaim or otherwise determine the use of a surplus;

- to modify, close or wind up a scheme." 38

As was pointed out to the Social Security Committee: "It is one of the last strongholds where we have seen little government intervention in the freedom to contract." 39

From being virtually unknown in large pension schemes in the nineteenth century, trust law was a useful and novel feature for occupational funds when proprietors first established occupational pension schemes for their workers in the first quarter of the twentieth century. It was favoured by liberal employers anxious to create harmonious relations and to share the administration with employees. It was soon realised that a trust was a cheap and effective vehicle because of its flexibility and the degree of de facto control which could be retained by appointing all the trustees. Not only this, but with the inflationary conditions of the First World War employers lobbied for exemption from taxation and in 1921 pressure from a group of backbenchers led to the implementation of the Finance Act 1921 which confirmed exemption from income tax of both employers' and employees' contributions to the funds and also exempted the whole of the investment income of the fund from taxation, tax being paid only on the pensions when they were paid; the additional benefit being that the funds are not vulnerable in the event of the failure of the company.

It is argued, however, that today the argument has moved on and that it is protection from the employer rather than protection from company creditors which is the aim. So, that trusts became the vehicle for the operation of occupational pension funds at all came about, not by deliberation as to the suitability of such a system, but because the Inland Revenue made it the basis upon which tax relief was granted, relief which in 1991/92 amounted to $£, 9,100$ million..$^{40}$

It is perhaps trite law that when assets are passed into a trust, they become trust property and as such although they legally belong to the trustees they must be used for the benefit of beneficiaries, the trustees falling under a fiduciary duty to exercise their powers for the benefit of the beneficiaries: the donor no longer having an interest in the property.

38. Para. 7.8.

39. Mr. Sean Hand, Social Security Committee, para. 42.

40. Leslie Hannah, Inventing Retirement - The Development of Occupational Pensions in Britain (1986). The Chancellor in his 1993 Budget announced a reduction in tax credits which pension funds can claim on dividends from $25 \%$ to $20 \%$. It is estimated that pension schemes will lose investment income, from April 1993, of around $£ 600 m$ a year: Newslines from the G.M.B.C Group, May 1993. 
Insofar as company pension schemes are concerned, however, this principle does not apply. The company becomes a beneficiary itself under the 1986 Finance Act which limits the surplus to be retained in the fund to $105 \%$. Any surplus in excess of that is to be penalised by the loss of tax relief.

This places the company in a severe conflict of interest which is aptly demonstrated in the disputed transfer by Lucas Industries of $£ 150$ million from its pension fund. ${ }^{41}$ In recent years there have been a number of well publicised surpluses and as a result conflicts involving companies, trustees and members in which the right to the surplus in the fund is central. ${ }^{42}$

A refund to the company is, of course, just one of the ways in which the company can benefit from a surplus. For example, perhaps the most spectacular of surpluses has been that of British Coal Industries Pension Fund, which was reported to have a surplus of $£ 1.4$ billion. ${ }^{43}$ Whilst approximately $70 \%$ of the surplus was allocated to improve benefits for scheme members, pensioners and those with deferred benefits, British Coal gained from the surplus in that it achieved a contribution holiday until the year 2000 , which accounts for the balancing $30 \%$ of the surplus. ${ }^{44}$ It has also been reported that British Rail recently agreed a contribution holiday worth over $\ell_{3} 300$ million. 45

British Coal is an industry which it is planned should pass from the public to the private sector and, as yet, despite opposition pressure no reassurances that the surplus will be used for the benefit of members has been forthcoming. Following the announcement by Michael Heseltine, President of the Board of Trade, of 30,000 redundancies in the pit closure programme, fears have been expressed that the Government will attempt to recoup some of the $£ 1$ billion redundancy costs by attempting to "siphon off" surpluses. ${ }^{46}$

41. The Times, 13 October 1992: "Lucas shake-up wipes out $£ 90 \mathrm{~m}$ pension surplus". Lucas Pensions Trust, a company in which the directors are equal numbers of management and union representatives, made scheme improvements for 30,000 employee members and 35,000 pensioners amounting to $£ 225$ million. It applied to the Occupational Pensions Board for the grant of a modification order to transfer $£ 150$ million (before tax). The company has had a pensions holiday since 1985 and in November 1991 after the order was granted, a transfer of a nett sum of $£ 90$ million was made to the company. However, some 79 individual beneficiaries are disputing the transfer and have issued a High Court writ against the trustees of the fund seeking the return of $£ 150$ million: Ids Pensions Service Bulletin, Issue No. 52: December/January 1992.

42. E.g., Molins pension fund surplus is reported to amount to $£ 390$ million and the company has put a proposal to the trustees that some of that be returned to the company: Daily Telegraph, 21 st March 1992; Stannad v. Fisons Pension Trust Ltd. [1990] P.L.R. 201.

43. The Times, 20th December 1991.

44. IDS Pensions Service Bulletin, Issue No. 58: September 1992.

45. Bargaining Report 111, November 1991.

46. Kirstie Hamilton, "Row brews over fate of Coal's pension surplus", Sunday Times, 18th October 1992.

During the passage of the Bill the Minister has come under pressure from backbench M.P.s to include in the bill security for preferential travel terms for those beyond state pension age and students. The question of the pension scheme and pension provision remains, however, subject only to Ministerial statements. 
The conflict arises most acutely when ownership of a company, along with the pension scheme, is transferred. The assets sitting in the fund may be irresistible and to resolve the conflict the law can only resort to the old common law duty of trust and confidence. 47

It is such situations that have led to a debate and legal action over who "owns" the funds, or for whose benefit funds accrued in a scheme in excess of that required to meet or provide for the set level of benefits, should be used. Whilst some employees can look forward to their pension as a matter of contractual right, ${ }^{48}$ it has been pointed out that in law the interests of beneficiaries are neither immediate nor directly measured by the value of the fund; employees acquiring rights to payment from the fund only when reaching normal pension age and then as provided for by the scheme rules. ${ }^{49}$ As for the surplus, beneficiaries have no legal right to participate in the surpluses in existing schemes, but likewise they are not to be irrevocably parted from them by the unilateral decision of a takeover raider with only a transitory interest in the share capital of the companies which employ them. ${ }^{50}$

It is against this rich backdrop, coupled with the fact that the pattern of working life today rarely, if ever, involves employment with one employer, but with a number of employers, and that interspersed with periods of employment may well be periods of unemployment, whether voluntary or involuntary, that pensions have taken on a high profile role. ${ }^{51}$ In addition, the Maxwell and other scandals concerning fraud have led to calls for "something to be done". That "something" may well involve the introduction of a standard trust deed for all company based schemes or it may involve a new model along the lines suggested by the Social Security Committee. Alternatively, there is a more radical approach: that the provision of income after retirement should be totally divorced from the employing company. ${ }^{52}$ The key characteristic of this pensions model is that accumulated benefits would be unaffected when employment is changed because the scheme would be completely independent of the employing company. Of

47. Imperial Group Pension Trust Ltd. v. Imperial Tobacco Ltd. [1991] 2 All E.R. 597.

48. Employment Protection (Consolidation) Act 1978, s.1 requires an employer to provide written particulars to all employees who fall within s. 1 of what amounts to the key terms of their employment contract. S.1(3)(d)(iii) requires any terms and conditions relating to pensions and pension schemes to be included. Although the statement has been held not to be a contract it is evidence of the contractual terms. Therefore the more detailed the statement, the greater the obligation on the employer to provide those benefits.

49. Supra n. 14, para. 9.3.

50. Courage Group Pension v. Imperial Brewing [1987] 1 All E.R. 528, per Millet J.

51. It is noted, Daily Telegraph, 31 st October 1992, "Inquiries on pensions nearly treble", that the number of inquiries received by the Occupational Pensions Advisory Service nearly trebled in the last 12 months.

52. David Blake, "It's time to take our pensions out of the hands of employers", The Times, 18th September 1992, argues that even if it was once the case that employees would remain in lifelong employment, pension schemes were then not for employees to save for their retirement, but for the employer to put money to one side for his employees' retirement. 
course, this overlooks the fact that the benefit to the employee of a company based scheme is that the employer is very often responsible for a significant percentage, sometimes all, of the contributions and that he often pays the life insurance premium which provides life cover for all members up to the permitted revenue limit. ${ }^{53}$ In addition, it is the employer in lean times who is often responsible under the trust deed for providing the funding should a deficiency occur - this is of course the argument used to demonstrate why it is he who should gain when the scheme is overfunded and in surplus. ${ }^{54}$

The Consultation Document issued by the Pension Law Review Committee ${ }^{55}$ raises a number of questions upon which it seeks views from as wide a spectrum as possible. ${ }^{56}$ It asks whether there is a case for abandoning the use of trusts and what other mechanism, which would offer improved protection, could replace it. It explores the different arguments advanced by employers for their right to determine the use of a surplus, and those advanced on behalf of employees, and seeks views on how the interests should be balanced, and goes on to ask whether there should be an Occupational Pension Scheme Act. The question is also raised of how disputes are resolved and whether there should be a specialist pensions tribunal. ${ }^{57}$ This was recommended in 1989 by the Occupational Pensions Board ${ }^{58}$ but was omitted from the 1990 Social Security Act, which implemented other recommendations, on grounds of cost. The question has arisen again recently with the first anniversary of Maxwell's death. It has been pointed out that "the sums paid to the corporate undertakers are mind-boggling. So far, the total is reckoned to be anything up to $£ 70$ million ...".59 This is a subject to which the Social Security Committee has now turned its attention, with particular reference to how much of the sum consumed on legal fees has been spent on fighting disputes between lawyers representing the different interests involved.

\section{Information}

The Social Security Committee recommended that each year contributors to, and beneficiaries of, occupational pension funds should receive an annual statement approved by the fund's auditor highlighting the value of their pension funds'

53. Currently four times pensionable salary.

54. In a survey conducted by actuary Towers Perrin, $80 \%$ of employers (representing one-third of the total membership and assets of the U.K. private pension schemes) believed it was the responsibility of the sponsoring employer to make good any shortfall in the fund, but most respondents thought any pension fund surplus belonged to the sponsoring employers and should not be given to members: Personnel Plus, August 1992.

55. See n. 14, supra.

56. Professor Goode wrote a letter to The Times on 20 th October 1992 in which he emphasised that the committee welcomed all views, whether or not they fitted into the structure of the Consultation Document, and pointing out that it was intended to hold three public hearings during the consultation period - in Birmingham, Edinburgh and London.

57. See n. 14, supra para. 18.3, question 75 .

58. Supra n. 31, para. 13.14-17.

59. "The fortune hunters", The Guardian, 5th November 1992. 
portfolio. In addition, the statement should indicate in what form the assets are held and where deposited, and individuals should also be given details of the value of their holding, together with a summary of the audited accounts and information of how to obtain a copy of the full accounts. Indeed, the Committee see the right to information of various kinds as a means of empowering members who should annually be given the opportunity of indicating whether or not a meeting of members should be held, and during which they could question trustees on their stewardship of the fund. Of course, the new disclosure of information requirements were recently brought into effect. However the volume of information and complexity of pension schemes may have the effect of rendering more information of little use to the average member.

\section{Fraud}

It appears that, Maxwell aside, the question of fraud is an increasing one. Mr. Sean Hand, who was appointed adviser to the Social Security Committee, when asked about the extent of pension fund fraud said: ". . . that the true answer is that nobody knows. There were, however, signs which suggested to him, ... that fraud 'may be fairly widespread'."60

In 1989, after Aveling Barford, a Grantham firm, went into receivership, it was discovered that $£ 1$ million had been transferred to the parent company. Since then in excess of $£ 6$ million of pension fund money has been recovered by Touche Ross, the trustee, and three men were convicted of conspiring to defraud the pension fund and received prison sentences from two to four years. ${ }^{61}$

This is not an isolated case. It is the sheer scale of the fraud in the Maxwell case that has attracted so much attention, but there have been a number of cases of missing pension fund money in the last two years and for members of all schemes, where benefits either suffer a reduction or are terminated as a result of fraud, it is a personal tragedy.

In March this year Gerald Smith, former Chief Executive of Farr construction group, which went into liquidation in December 1990, appeared before Magistrates at Bow Street facing 14 charges that allege he stole $£ 1.2 \mathrm{~m}$ from the company's pension fund.

When Bradstock Trustee Services was appointed independent trustee for the Peak Design Ltd. Pension Scheme, which went into receivership, they found around $\mathcal{f} 1$ million was missing from the pension fund and the Derbyshire Fraud Squad have been brought in to investigate some aspects of the scheme's affairs. ${ }^{62}$

Following the appointment as independent trustee for the Lewis's department store chain, Law Debenture Trust Corporation is reported to be considering taking legal action against the pension fund trustees, advisers and agents over 
allegations that over $£ 4$ million is missing from the fund. ${ }^{63}$

After Belling \& Company, an old established North London firm, went into receivership in May 1992, the Independent Trustee reported that the trustees of the pension fund bought a company in November 1991 from Belling for a sum representing $20 \%$ of the pension scheme's assets and although the company was trading profitably, much of its trade was with Belling. In addition, the independent trustee is investigating an investment of $£ 2.1$ million which Belling used as an advanced payment on a refinancing arrangement which did not go ahead, but the money was not repaid. Until such time as these two matters have been resolved, although pensions in payment will continue, early retirement and payment of transfer values will not be possible. ${ }^{64}$

At a time of diminishing company fortunes, pension funds have prospered and have by and large accumulated large surpluses by a combination of overfunding, unpredicted stock market performance and large scale reductions in the workforce. As workforces continue to be compulsorily reduced on an unprecedented scale, pension funds will get richer at the very time that company performance and profitability continues to deteriorate. ${ }^{65}$ The temptation to regard pension fund surpluses, or even pension fund assets, as 'available' to an ailing company will grow and the question of the ownership and treatment of surpluses will increase in intensity both in the private sector, ${ }^{66}$ but perhaps particularly in the public sector where pension provision has been generous and there has in the past few years been a massive transfer of labour into the private sector, with consequent pension problems. ${ }^{67}$

\section{Trustees}

It is the trust deed which specifies the power to appoint and to dismiss trustees and it is very often the sponsoring company who retains this power. The Pensions Law Review Committee point out that the employer will normally appoint and remove trustees and that the majority of trustees are usually drawn from the senior

63. IDS Pensions Service Bulletin, April 1992.

64. IDS Pensions Service Bulletin, Issue No. 58: September 1992.

65. "Fraud flourishes across UK", The Times, 2 1 st November 1992: "KPMG Peat Marwick ... has compiled a 'fraud barometer' that tracks case of fraud involving $£ 100,000$ or more. By June 18,1992 the value of reported fraud . . had overtaken the total of $£ 376$ million recorded in 1991, itself 64 per cent up on the previous year. By the end of August, the UK fraud total had reached $£_{4} 45$ million. ... KPMG's fraud specialist says the recession is flushing out tricksters like rats from a sinking ship."

66. See Imperial Group Pension Trust Ltd. v. Imperial Tobacco Ltd. [1991] I.C.R. 524; Stannard v. Fisons Pension Trust Ltd. [1992] I.R.L.R. 27; Ryan v. Imperial Brewery $\mathcal{E}^{\circ}$ Leisure Ltd. [1987] 1 All E.R. 528; Richard Nobles, "Who is Entitled to the Pension Fund Surplus?", I.L.F. (1987) September.

67. 1.e., "Post workers face loss of pensions", Personnel Today (1992), 29th September, "Qa pensioners shocked by figures that don't add up", Daily Telegraph, 7th November 1992. Qa Business Services was formerly the management services division of the West Midlands Regional Health Authority and was bought by its managers in 1989 . 
management of the company. ${ }^{68}$ The Select Committee highlighted the inability of trustees who are employed by the company, however senior, to exercise their functions independently and in the interests of members when faced with an employer who holds the power of dismissal and is prepared to exercise that power. They recommend that independent custodian trustees should be appointed to hold pension fund investment assets and that all pension fund share documents should clearly have their ownership designated on them.

There appears to be widespread support for at least one trustee to be independent ${ }^{69}$ and in evidence to the Select Committee the Pensions Management Institute, in advocating improved stewardship of pension schemes, recommended that each scheme should have an independent trustee and that in addition the powers of the Pensions Ombudsman, set up by the Social Security Act 1990 to hear complaints by members of maladministration by trustees or managers, should be expanded to enable him to hear complaints by trustees or pensions managers, and that he should have powers to protect "whistle blower" trustees.

At present the only requirements for an independent trustee is when an insolvency practitioner begins to act in relation to a company. Under the Social Security Act 1990 he is obliged to ensure that there is an independent trustee of the company's pensions scheme, and once in place he can only be removed by the court.

There is an increasing tendency for workforce representation on the Board of Trustees and it would appear appropriate that, not only should the Ombudsman's powers be extended in order that he may hear trustees, but that protection be afforded to employee trustees similar to that provided by the Employment Protection (Consolidation) Act 1978, section 58 in connection with trade union membership. ${ }^{70}$

The Trade Union Reform and Employment Rights Bill contains protections against dismissal for employees who "whistle blow" in connection with dangerous working practices, similar to those which protect those carrying out trade union duties. This recognises that the employee who turns "whistle blower" is extremely vulnerable and the same can be said of the "worker trustee" who, without protection, becomes a mere token.

A campaign has been initiated by G.M.B., T.G.W.U. and M.S.F. unions for legislation which would compel pension trust boards to give a majority of seats to

68. Para. 10.1 .

69. John Jolliffe, "The Independent Trustee", Sol. fo. (1992), 20th March, summarises the proposals set out in a paper submitted to the Pensions Management Institute which was prepared by a group promoting the concept of independent trusteeship.

70. The Society of Pension Consultants in "Occupational Pensions After Maxwell", June 1992, para. 4.3.10, expressed the wish to see greater security of tenure for member trustees, involving limits on the employer's power to dismiss them as trustees and/or employees and suggests that in the same way that dismissal from employment arising from trade union activity is a ground for complaint to an industrial tribunal, so should be dismissal arising from legitimate action as a trustee. 
pension fund members. Likewise the Institute for Public Policy Research has published a report putting forward a number of specific proposals for changes in the law to ensure better protection of workers' pensions and in particular that at least two-thirds of a scheme's trustees should be appointed by scheme members, including pensioners and deferred pensioners, and that there should be entrenched rights for member trustees, including security of employment and time off with pay to carry out their duties. ${ }^{71}$ Only $38 \%$ of those surveyed by Towers Perrin $^{72}$ agreed that half the trustees should be elected by employees, and $49 \%$ disagreed. The report points out that independence of the chairman of the trustees from day-to-day management of the sponsoring employer was not seen as necessary; nor was the requirement that separate advisers be appointed to trustees. Advisors are usually appointed by the sponsoring company and in such circumstances see their role as acting in the best interests of the company.

Browne-Wilkinson LJ in a paper delivered to the National Superannuation Conference in Melbourne in February 1992 listed ten modifications to trust law which, in his view, are necessary. Amongst these are that at least one of the trustees should be wholly independent of the employer; that in larger schemes at least, the trust assets should be held by an approved, independent Custodian trustee; that the employer should not have power to remove a trustee and that trustees should always have separate legal advice from that of the company. Towers Perrin point out in their survey ${ }^{73}$ that with the more rigorous definition of independence adopted in the Social Security Act 1990 in the event of insolvency, in practical terms, with thousands of pension schemes but so few truly independent professional trustees, it is difficult to see a mandatory independent trustee being so rigorously defined and that, in their opinion, it is far more important for all trustees to have access to exclusive and unbiased advice.

The Society of Pension Consultants consider that "rather than have a right to seek independent advice, members of a trustee body who find themselves in a minority, and who feel that there is cause for concern arising from actions agreed by the majority of trustees, should have the right to take their concern to an appropriate watchdog body ..." which may be a restructured Occupational Pensions Board as suggested by the Social Security Committee, or a tribunal, and they stress that it is desirable to establish an overall watchdog body for occupational pension schemes.

One of the difficulties faced by member trustees is that not only are they subject to employer pressure, but the law relating to pension schemes is diverse and complex. The Pensions Management Institute has launched a Trustee Certificate aimed at providing those trustees who wish to sit the examination with formal

71. "Locking the stable door - the ownership and control of occupational pension funds", Bargaining Report 116, April 1992.

72. See n. 54.

73. See n. 54. 
recognition that they have basic knowledge of trust law and associated pensions legislation. ${ }^{74}$ In addition the Occupational Pensions Board have issued a guide for pensions trustees which under the Disclosure of Information Regulations, which came into effect in September $1992,{ }^{75}$ must be put into the hands of all trustees and a statement is required to be made in the accounts that all trustees have been given a copy. ${ }^{76}$

\section{Regulation}

The Select Committee examined the roles of the various watchdog bodies Occupational Pension Board (OPB), Occupational Pensions Advisory Service (OPAS), Superannuation Funds Office (SFO), from April 1992 known as Pension Schemes Office (PSO), and IMRO upon whom the Committee comment: "... this aspect of the system of self-regulation is - when the chips are down little short of a tragic comedy." The Committee recommend that the OPB be reconstituted with additional powers and that it become the main regulatory agency for occupational pensions, with responsibility for supervising the training of trustees and power to place assets of pension funds under the control of an approved trustee if the assets are at risk.

The Pension Law Review Committee note all the bodies officially concerned with pensions and comment that the legal framework within which pension schemes operate is extremely complicated and that regulatory control is fragmented with no single body responsible for the full range of schemes' noninvestment activities. It asks whether there should be a new body or an existing body with expanded powers and what the role of the OPB should be in any new regulatory system. ${ }^{n}$

The view has been expressed that at the end of the day, as with any reform, "the acid test is whether these measures would withstand the sustained assault of a determined and persistent marauder. A set of mousetraps, however elaborate, will not deflect the charge of a rogue elephant." 78 A determined fraudster will inevitably find a way round whatever regulations and supervision there may be. There appears, however, to be a measure of agreement that rather than increase regulation in an already over regulated sector, which will place additional burdens on employers, what is required is an effective mechanism to identify those funds with few and declining safeguards and provide sufficient powers for a newly constituted Occupational Pensions Board to intervene. The question is, of course, what is the extent of the funds with declining safeguards?

74. IDS Pensions Service Bulletin Issue No. 58: September 1992.

75. See no. 25.

76. "The Occupational Pensions Board Guide for Pension Trustees", HMSO, January 1992.

77. Paras. 18.1 and 18.2.

78. Bacon \& Woodrow, Analysis No. 74, 11 th February 1992. 


\section{Summary}

Following the Maxwell affair, the Government has the task of restoring public confidence in pension funds as a means of saving for retirement.

There appears to be a widespread view that following the Maxwell scandal it is necessary to wipe the slate clean from a mish mash of tax and social security legislation and trust law and start afresh with a statutory framework. ${ }^{79}$ Finding a framework which achieves the dual goal of reassuring employees of the security and management of their future pension, and at the same time avoids the introduction of increased complexity and cost, is a balancing act which will require a fair degree of skilled footwork. If the right balance is not struck employers will decide not to continue to operate a pension scheme, preferring to let employees contract back into the state scheme.

The Social Security Committee noted that "something like 3,500 schemes sought surrender or cancellation of their contracting-out certificates last year, mainly due to the recession ...". ${ }^{80}$ This is a worrying trend and it is notable that even the introduction of the Disclosure of Information regulations ${ }^{81}$ with its consequent additional burden on personnel departments, has caused some companies to wonder whether the burden of continuing to operate an in-house scheme is worthwhile. ${ }^{82}$ At the very least, there has been a progressive move in the private sector away from final salary schemes to money purchase schemes whereby the fund which accumulates at the end of the day is very much a product of how the investments perform and there is no guarantee of a given percentage of final salary.

In recent years, the Government has been attempting, by the use of incentives, to reduce dependency on the State Earnings Related Superannuation Scheme (SERPS), ${ }^{83}$ as well as the benefits to be obtained from it, because of the fears of increasing costs at a time of demographic change. It is projected that by the year 2050 those over state pension age will increase from 10.3 million to 13.3 million, peaking at 14.4 million in 2034 when the 1960 's baby boom reaches retirement age. At the same time the working age population is expected to fall from 34.4 million to 33.6 million by 2050 . Because the state scheme is a pay as you go scheme and not

79. In evidence to the Social Security Committee Miss Dawes of the OPB "recalled that, on average, one Act was passed each year affecting pension funds and that there now exists 'about 2,500 pages of statute law ... designed to protect members'.": para. 55.

80. Para. 197.

81. See n. 25.

82. "Changes to pension rules could mean more work for Personnel Department . . .". "The rules also mean personnel departments will have to ensure the performance of their schemes is listed over a rolling 10-year period. Actuary Gordon Mitchell said this will cause confusion since performance figures are dependent on inflation. He believes within a decade some firms may find it easier to drop pension schemes altogether.": Personnel Today, 13th October 1992.

83. The Daily Telegraph, 21 st November 1992, reported that the Government had announced further incentives for those contracted out of SERPS to remain out from April when otherwise it would have been favourable for them to return, by the announcement of an additional $1 \%$ rebate of National Insurance contributions and hinted that it may introduce further age-related rebates to encourage older people to remain contracted out of SERPS. 
actuarially based, the support ratio (the ratio between the working population and those in retirement) is important. At the same time as the increase in those in receipt of pension, it is expected that those of working age will decline, reducing the ratio from 3.4 in 1990 to 2.6 by 2050 , a fall of $24 \%$, reaching a low point of 2.4 in 2030. This suggests that the capacity of the economy to support its much larger pensioner population will come under considerable pressure. ${ }^{84}$

This problem has been compounded by the recession which has seen large numbers of people being made redundant. For those who were members of a final salary company pension scheme their plans and hopes for a retirement in which they would enjoy a pension of up to two-thirds final salary have evaporated. For those who were members of money purchase schemes and who are now unemployed, because their contributions have ceased their fund will stagnate; and those who accepted Government incentives and set up personal pension arrangements will be faced, in the event of unemployment, of letting the policy lapse or making it paid-up. Whichever type of scheme the unemployed person was a member of the effect on the State when these people reach retirement age, whenever that might be, will undoubtedly be a massive financial burden. The recession of the early 1990's will see a whole generation of people who previously thought that they were going to be adequately provided for in their retirement become, in differing degrees, a burden on the state at a time when the state is least able to afford it. ${ }^{85}$

For pension schemes where large numbers of members have become early leavers as a result of redundancy, large surpluses will accrue bringing to the forefront again the question of pension holidays, repayment of surplus to the company, and even more controversially of what happens to the fund of money should the company be purchased or taken over.

84. Supra no. 8.

85. 1993 is the European Commission's Year of Older People and will focus on employment and social issues for older people. The Carnegie Inquiry, launched by the Carnegie U.K. Trust in 1990 to look at the work and livelihood of people age 50-75, published its report Life, Work and Livelihood in the Third Age in April 1993. 